\title{
ASSOCIATION OF LAMOTRIGINE AND VALPROATE IN REFRACTORY EPILEPSIES OF CHILDREN AND ADOLESCENTS
}

\author{
Karen P. Grisotto', Isac Bruck², Sérgio A. Antoniuk², Lúcia H.C. Santos ${ }^{3}$
}

\begin{abstract}
Objective: To evaluate the efficacy or eventual side-effects of the association of lamotrigine and sodium valproate in the control of refractory epilepsies. Method: A retrospective analysis of 37 children with a mean age of 12 years taking exclusivelly lamotrigine and sodium valproate. Efficacy of seizure control was considered satisfactory if there was a reduction in seizures $\geq 50 \%$ or total control. Results: The association of lamotrigine and sodium valproate was considered satisfactory in $65 \%$ of the studied children, independent of seizure type. Total seizure control was obtained in $33 \%$ and $35 \%$ had an unsatisfactory response or remained unchanged. Primary generalized tonic clonic seizures were the most common type with $84 \%$ of day-time seizures having a good response to treatment. Side-effects were seen in $11 \%$ of patients and the most common was tremor. Conclusion: Total or satisfactory control of seizures was seen in the majority of patients and sideeffects were uncommon.
\end{abstract}

KEY WORDS: epilepsy, refractory, valproate, lamotrigine, childhood.

\begin{abstract}
Associação de lamotrigina e valproato de sódio no tratamento de epilepsia refratária em crianças e adolescentes
Resumo - Objetivo: Avaliar a eficácia ou eventuais efeitos colaterais da associação de lamotrigina e valproato de sódio no controle de epilepsia refrataria. Método: Análise retrospectiva de 37 crianças e adolescentes com idade média de 12 anos tratadas exclusivamente com lamotrigina e valproato de sódio. A eficácia do controle de crises foi considerada satisfatória se o controle das crises foi $\geq 50 \%$ ou total. Resultados: A associação de lamotrigina e valproato de sódio foi considerada satisfatória em $65 \%$, independente do tipo de crise. 0 controle total de crises foi obtido em $33 \%$ e em $35 \%$ a resposta foi insatisfatória ou permaneceu inalterada. Crise generalizada primaria tônico clonica foi o mais comum, com $84 \%$ das crises ocorrendo durante o dia, com boa resposta ao tratamento. Efeitos colaterais foram vistos em $11 \%$ dos pacientes, sendo tremor o mais freqüente. Conclusão: Controle total ou satisfatório das crises ocorreu na maioria dos pacientes, sendo pouco freqüente os efeitos colaterais.
\end{abstract}

PALAVRAS-CHAVE: epilepsia, refrataria, valproato, lamotrigina, criança.

Patients with recent diagnoses of epilepsy are preferably treated with monotherapy ${ }^{1}$. In the vast majority, the prognosis of these patients becomes apparent in a few years after starting their treatment. Around $10 \%$ of patients who initialy had a good response to the first treament have a reccurence of seizures and end-up with a difficult control ${ }^{2}$. When patients keep on having seizures despite adequate treatment with at least two first-line antiepileptic drugs, diagnoses of refractory epilepsy should be considered ${ }^{3}$. As a result, most patients with refractory epilepsy are treated with politherapy, which in turn has risen the concerning for the use of new drugs in an add on association that might be beneficial in such cas$\mathrm{es}^{4}$, thus avoiding the direct toxic effects of combining multiple drugs or the adverse effects resulting from their interaction?'

Lamotrigine (LMT) is considered to be an effective drug in the control of partial seizures with or without secondary generalization, as well as in generalized epilepsies with multiple seizure types ${ }^{5}$. A so-called therapeutical synergism of LMT with sodium valproate (VPA) has been hypothesized and there are many studies which point toward a beneficial response when they are used together ${ }^{1,46-8}$.

Pisani et al.' had an improvement in seizure control of

Centre of Neuropediatrics, Department of Pediatrics, Hospital de Clínicas, Universidade Federal do Paraná, Curitiba PR, Brazil (UFPR): 'Resident in Neuropediatrics, UFPR; ${ }^{2}$ Assistant Professors, Department of Pediatrics, UFPR; ${ }^{3}$ Adjunct Professor, Department of Pediatrics, UFPR.

Received 12 February 2008, received in final form 13 May 2008. Accepted 6 June 2008.

Dr. Isac Bruck - Rua Floriano Essenfelder 81 -80060-270 Curitiba PR - Brasil. E-mail: ibruck@terra.com.br 
complex partial seizures when the two drugs were used together, as compared to the isolated use of each one of them and this same synergic effect was seen in other seizures types ${ }^{9,10}$. The mechanism of action behind this association seems to be due to an inhibitory effect of VPA in the hepatic metabolization of LMT, thus reducing its clearance and elevating its serum levels ${ }^{4,7,8}$. There are some reports on higher incidence of skin rash when LMT is associated with VPA, though it still is not clear whether this side-effect is due to a rapid elevation of serum levels of LMT or if there is a sort of "immunological" synergism between the two drugs ${ }^{6}$.

The aim of this study was to evaluate the efficacy of the association of LMT and VPA in refractory epilepsies of childhood, as well as their eventual side effects.

\section{METHOD}

We performed a retrospective study of 37 children who were regularly seen in the Epilepsy Out-patient Clinic of the Centre of Neuropediatrics of the Hospital de Clínicas - UFPR from January 2002 to January 2006.

Data regarding efficacy and adverse effects were collected by interviwed with parents and caretakers. In addition we analised frequency/control of day-time and nocturnal seizures, etiology, seizure types, doses of medications and side effects, as reported by the children's parents and caretakers after the introduction of the two medications.

Inclusion criteria were: 1) a diagnosis of refractory epilepsy with at least one weekly seizure, 2) previous monotherapy or association of first-line drugs without seizure control and 3) exclusive use of LMT and VPA.

Exclusion criteria were: 1) association of other anti-epileptic drugs. 2) diagnosis of progressive encephalopathy. 3) presence of chronic liver or renal diseases. 4) occurrence of side-effects by the use of previous anti-epileptic drugs.

Treatment efficacy was based on the precentage of seizure reduction when compared to baseline prior to the use of the two medications. Frequency of seizures before and after the treament was quantified only by the use of seizure diaries, where the parents and caretakers wrote their own personal observations regarding the number os seizures, seizure type, seizure duration, time at which each individual seizure occured and possible trigger factors such as fever.

Treatment response was considered satisfactory when there was a reduction of seizure frequency of at least $50 \%$ or greater or total control. If the reduction was fewer than $50 \%$ or if there was no change in the frequency, treatment response was considered unsatisfactory.

LMT was added to VPA and doses were titrated based on Guberman et al." scheme, starting with $0.2 \mathrm{mg} / \mathrm{kg} /$ day, until a maximum of $6 \mathrm{mg} / \mathrm{kg} /$ day, or on lower doses if total control of seizures were achieved.
Due to the low socio-economical level of the study population, the drugs used in the study were given to the patients by the local Public Health institution.

This retrospective study was approved by the ethics committee of the "Hospital de Clínicas da Universidade Federal do Paraná".

\section{RESULTS}

We selected 109 patients of a tertiary reference center of Neuropediatrics using a combination of LMT and VPA for chart and file review. Of all these patients, only $37(34 \%)$ fullfiled the inclusion criteria

Mean age was 12 years, raging from 3 to 22 years. Gender distribution was as follows: 12 (32.5\%) children and adolescents were female and 25 (67.5\%) were male.

Seizures were primarily generalized in 31 (84\%) patients and partial in the remaining $6(16 \%)$.

In relation to the etiology, 19 (51\%) were classified as criptogenic, 14 (38\%) symptomatic and 4 (11\%) had idiopatic epilepsy. All the 4 patients with idiopatic epilepsy had a diagnosis of juvenile myoclonic epilepsy. Individual patients demographics are detailed in Table 1. Nine (24\%) patients had a diagnosis of cerebral palsy, with hypoxic-ischemic injury as the most common cause in $6(16 \%)$, followed by sequelae of meningites as the cause in $3(8 \%)$ children.

Mean duration of epilepsy was 8 years, ranging from 18 months to 21 years.

At the time LMT was added to the therapeutical regimen, 30 (81\%) patients were already taking VPA, while in the others the association of the two drugs started simultaneously.

A satisfactory treatment response was obtained in 24 (65\%) children, with total control in $9(24 \%)$ of them. An unsatisfactory response occured in $12(32.5 \%)$ patients, with a seizure reduction of less than $50 \%$ in $3(8 \%)$, worsening of seizures in $9(24 \%)$ and no change in seizure frequency in $1(3 \%)$ patient. (Table 2 )

In relation to the period of the day in which seizures occured, 20 patients had seizures only during day-time, 7 only had nocturnal seizures and 10 patients had seizures during the day and nocturnal. Some patients had more than one type of seizure.

Day-time seizures were primarilly generalized tonicclonic seizures (GTC) in 12 (60\%) patients, atonic in 5 (25\%), myoclonic in 7 (35\%) and partial seizures in 4 (20\%). Total control of day-time seizures was obtained in $6(30 \%)$ patients, all of them had primary generalized tonic-clonic seizures.

Nocturnal seizures were of the GTC type in 2 (29\%) patients and myoclonic in 5 (71\%), with a total control in only $1(15 \%)$ patient who had GTC seizures.

For those patients who had seizures during the day and noturnal, 7 (70\%) had GTC, 4 (40\%) had myoclonic 
Table 1. Demographics of patients.

\begin{tabular}{|c|c|c|c|c|c|c|c|}
\hline Patient & Gender & $\begin{array}{c}\text { Age } \\
\text { (years) }\end{array}$ & $\begin{array}{l}\text { Seizure } \\
\text { type }\end{array}$ & $\begin{array}{c}\text { Duration of } \\
\text { epilepsy (years) }\end{array}$ & Etiology & Diagnosis & $\begin{array}{c}\text { Response to } \\
\text { treatment }\end{array}$ \\
\hline 1 & M & 17 & CPS GM & 7 & $\mathrm{C}$ & - & $\geq 50 \%$ \\
\hline 2 & M & 22 & GM GTC & 21 & $\mathrm{C}$ & - & Worsening \\
\hline 3 & $\mathrm{~F}$ & 18 & ATAG & 15 & C & - & Free \\
\hline 4 & M & 16 & GM & 14 & 1 & - & Worsening \\
\hline 5 & $M$ & 16 & CPS-G & 15 & $S$ & Schizencephaly & $\geq 50 \%$ \\
\hline 6 & $M$ & 15 & GTC & 12 & $S$ & Ito's Hypomelanoses & $\geq 50 \%$ \\
\hline 7 & M & 16 & CPS GTC & 3 & $\mathrm{C}$ & - & Worsening \\
\hline 8 & M & 13 & GM GTC & 4 & C & - & $\geq 50 \%$ \\
\hline 9 & $F$ & 17 & ATAG GTC & 4 & C & - & Worsening \\
\hline 10 & M & 13 & SP-G AG & 10 & $S$ & Lissencephaly & Free \\
\hline 11 & M & 10 & GM & 10 & I & - & $<50 \%$ \\
\hline 12 & $M$ & 18 & GM & 16 & 1 & - & Worsening \\
\hline 13 & M & 11 & GTC & 9 & $S$ & Meningites & $\geq 50 \%$ \\
\hline 14 & M & 17 & CPS & 4 & $\mathrm{~S}$ & MTS & $\geq 50 \%$ \\
\hline 15 & $M$ & 17 & CPS & 10 & C & - & $\geq 50 \%$ \\
\hline 16 & $\mathrm{~F}$ & 13 & CPS-G GTC & 13 & $S$ & HIS & $\geq 50 \%$ \\
\hline 17 & $\mathrm{~F}$ & 14 & GTC & 9 & C & - & $<50 \%$ \\
\hline 18 & $M$ & 13 & GTC & 6 & C & - & Free \\
\hline 19 & M & 8 & GC GTC & 3 & $S$ & Meningites & Worsening \\
\hline 20 & M & 16 & GTC & 6 & $\mathrm{~S}$ & Meningites & Free \\
\hline 21 & $M$ & 13 & GM & 7 & C & - & Free \\
\hline 22 & $\mathrm{~F}$ & 9 & GTC AG & 8 & C & - & Worsening \\
\hline 23 & M & 12 & GTC & 7 & C & - & $\geq 50 \%$ \\
\hline 24 & $\mathrm{~F}$ & 13 & GM GTC & 12 & $S$ & HIS & $\geq 50 \%$ \\
\hline 25 & $\mathrm{~F}$ & 13 & SP-G & 9 & C & - & Free \\
\hline 26 & M & 16 & SP & 12 & C & - & $\geq 50 \%$ \\
\hline 27 & $M$ & 6 & GM GTC & 6 & $S$ & HIS & $\geq 50 \%$ \\
\hline 28 & M & 8 & GA $\quad$ GT & 4 & $\mathrm{~S}$ & Tuberous sclerosis & Unchanged \\
\hline 29 & M & 7 & GTC & 4 & C & - & $\geq 50 \%$ \\
\hline 30 & $F$ & 8 & CPC & 7 & C & - & $\geq 50 \%$ \\
\hline 31 & $\mathrm{~F}$ & 10 & SP-G & 5 & C & - & $<50 \%$ \\
\hline 32 & $\mathrm{~F}$ & 3 & GTC & 3 & $C$ & - & $\geq 50 \%$ \\
\hline 33 & $\mathrm{~F}$ & 3 & GM GT & 3 & $S$ & HIS & Free \\
\hline 34 & $\mathrm{~F}$ & 9 & ATAG GTC & 4 & C & - & Worsening \\
\hline 35 & M & 3 & GM & 1 & 1 & - & Worsening \\
\hline 36 & $M$ & 3 & GTC & 3 & $\mathrm{~S}$ & HIS & $\geq 50 \%$ \\
\hline 37 & $M$ & 5 & GT & 3 & $S$ & HIS & Free \\
\hline
\end{tabular}

CPC, complex partial seizure; SP, simple partial seizure; CPS-G, complex partial seizure with secondary generalization; SP-G, simple partial seizure with secondary generalization; GM, generalized myoclonic; GTC, generalized tonic-clonic; AG, atonic; ATAG, atypical absence seizure; GT, tonic; GC, clonic; C, criptogenic; S, symptomatic; I, idiopatic; MTS, mesial temporal sclerosis; HIS, hipoxic-ischaemic syndrome.

Table 2. Seizure control while in the use of the association of LMT and VPA.

\begin{tabular}{|c|c|c|c|c|c|}
\hline Seizure type & $\begin{array}{c}\text { Total control } \\
\mathrm{n}(\%)\end{array}$ & $\begin{array}{c}\text { Control } \geq 50 \% \\
n(\%)\end{array}$ & $\begin{array}{c}\text { Control }<50 \% \\
n(\%)\end{array}$ & $\begin{array}{c}\text { Worsening } \\
\text { n (\%) }\end{array}$ & $\begin{array}{c}\text { Unchanged } \\
\mathrm{n}(\%)\end{array}$ \\
\hline Generalized (n:31) & $8(21.5)$ & $11(30)$ & $2(5.5)$ & $9(24)$ & $1(3)$ \\
\hline Partial (n:6) & $1(3)$ & $4(11)$ & $1(3)$ & 0 & 0 \\
\hline
\end{tabular}


Table 3. Comparison of incidence adverse effects with the addition of LMT to VPA.

\begin{tabular}{cccc}
\hline $\mathrm{n}(\%)$ & $\begin{array}{c}\text { UFPR* } \\
\mathrm{n}=37\end{array}$ & $\begin{array}{c}\text { Faught et al. }^{6} \\
\mathrm{n}=108\end{array}$ & $\begin{array}{c}\text { Thomé et al. }^{4} \\
\mathrm{n}=28\end{array}$ \\
\hline Skin rash & 0 & $9(15 \%)$ & $2(7 \%)$ \\
Irritability & $1(3 \%)$ & $4(4 \%)$ & 0 \\
Tremors & $2(5,5 \%)$ & 0 & $6(21 \%)$ \\
GI Symptoms ** & $1(3 \%)$ & $10(9 \%)$ & 0 \\
\hline
\end{tabular}

* Universidade Federal do Paraná; **Gastrointestinal symptoms.

seizures and $3(30 \%)$ atonic seizures. In this group, 4 (40\%) had total seizure controle while two (20\%) patients kept on having myoclonic seizures.

Adverse events ocurred in $4(11 \%)$ patients: two of them $(5.5 \%)$ presented with tremors, $1(3 \%)$ had irritability and 1 (3\%) had gastrointestinal symptoms (Table 3). None of the subjects developed a skin rash during the course of treatment and the adverse effects were not considered severe to the patient health, so that they did not warrant interruption of the medication

\section{DISCUSSION}

Recent studies have shown that the concomitant administration of LMT and VPA might be a reasonable option in order to obtain a better seizure control in refractory epilepsy, ${ }^{4,9}$. Thome et al. ${ }^{4}$ reported the results of the first exclusive pediatric group. Our study evaluates a population of children and adolescents who exclusivelly were taking the combination of LMT and VPA and this drug-association proved effective in controlling seizures in $65 \%$ of our patients.

Pisani et al.' in their study had a different approach, using each drug isolated, only combining them if they had an unsatisfactory response. He noticed a remarkable reduction in seizure frequency when both drugs were used toghether: $61 \%$ of patients had a reduction in their seizure frequency of more than $50 \%$ and $31 \%$ were seizure-free. Also, Brodie et al. ${ }^{12}$ in a multicentric study observed that the addition of LMT resulted in a better clinical response in those patients already taking VPA when compared to those using carbamazepine or phenytoin. Although it was not possible to have the drugs blood level and be sure of compliance to treatment, we have similar results of the cited authors with $65 \%$ of patients having a significant reduction of seizures and $24 \%$ with complete control.

Patients with unsatisfactory control where those who had multiple seizure types with myoclonic seizures beign the most resistant to treatment, persisting mostly at night. Of the 9 patients who had a worsening of seizure frequency, 4 of them had myoclonic seizures. Donaldson et al. ${ }^{13}$ in his study of patients diagnosed with Lennox-Gastaut syndrome noticed that adjunctive theraphy with LMT was favorable for controlling tonic, atonic, tonic-clonic and atypical absence seizures, but not for myoclonic seizures. Altough there are some favorable reports on the combination of LMT and VPA in the control of partial seizures', typical absence seizures ${ }^{9,10}$, myoclonic seizures ${ }^{14}$ and infantile spasms ${ }^{15}$, the real effect on myoclonic seizures is a controversial issue. Brodie et al. ${ }^{12}$ reported that those patients with idiopatic GTC seizures had a better response to treament than those with partial seizures (with or without secondary generalization). Trevathan et al. ${ }^{16}$ reported the same good control of primary tonic-clonic generalized seizure, in a subgroup of 14 children age 2 to 20 years old of a randomized clinical trial, but they were also on 1 or 2 concurrent anti epileptic drugs (AEDs). In our study we also noticed that patients with generalized tonic clonic seizures had a more satisfactory control.

Skin rash, when it occurs, is maculo-papular in nature, usually developing over a few weeks after the introduction of LMT and rapidly resolving after it's withdrawal. This idiosynchratic reaction seems to be independent of dose and is mediated by a type IV hypersensibility reaction $^{12}$. Guberman et al." reported that children who were at higher risk of developing rash as an adverse side-effect of LMT were those who were taking VPA in combination. Converselly, Thomé et al. ${ }^{4}$ and Faught ${ }^{6}$ had low incidences of rash with the use of LMT and believed that this was due to a slow and gradual introduction of the drug. Even though a synergic effect of these drugs can be seen,increasing the risk of toxic levels, thus resulting in more side-effects, we did not have a higher incidence of such adverse effects in our patients. Probably due to the low doses that we started and gradual increase of subsequent doses of LMT we didn't have skin rash and the sideeffects, when they occured, were considered mild and did not warrant the withdrawal of the drugs.

According to Pisani et al.' there is strong evidence that the combination of these drugs might be peculiarly efficient for those patients with refractory epilepsy. Several mechanisms of action are beign studied to evaluate the benefits of this association. Most of the studies point- 
ed to the potentialization of the effects of LMT, by VPA through the inhibition of hepatic glucoranidation of LMT with an increase in it's serum levels.

Our results corroborate the hypothesis that the combination of LMT and VPA is both benefitial and safe. A good proportion of satisfactory seizure control was obtained when the use of either drug isolated was unsuccesfull.

In conclusion, our study confirm the published evidence that LMT and VPA have a favorable therapeutical interaction in patients with refractory epilepsy and highlights the use of both drugs toghether, even in those patients who had previously used either drug independently.

\section{REFERENCES}

1. Pisani F, Oteri G, Russo MF, Di Perri R, Perucca E, Richens A. The efficacy of valproate-lamotrigine comedication in refractory complex partial seizures: evidence for a pharmacodynamic interaction. Epilepsia 1999;40:1141-1146.

2. Mohanraj R, Brodie MJ. Diagnosing refractory epilepsy: response to sequential treatment schedules. Eur J Neurol 2006;13:277-282.

3. Kwan P, Brodie MJ. Refractory epilepsy: a progressive, intractable but preventable condition? Seizure 2002;11:77-84

4. Thomé-Souza S, Freitas A, Fiore LA, Valente KD. Lamotrigine and val- proate: efficacy of co-administration in a pediatric population. Pediatr Neurol 2003;28:360-364.

5. Placidi F, Marciani MG, Diomedi M, Scalise A, Giacomini P, Gigli GL. Effects of lamotrigine on nocturnal sleep, daytime somnolence and cognitive functions in focal epilepsy. Acta Neurol Scand 2000;102:81-86.

6. Faught E, Morris G, Jacobson M, et al. Adding lamotrigine to valproate: incidence of rash and other adverse effects. Epilepsia 1999;40:1135-1140.

7. Kanner AM, Frey M. Adding valproate to lamotrigine: a study of their pharmacokinetic interaction. Neurology 2000;55:588-591.

8. Mataringa MI, May TW, Ramberck B. Does lamotrigine influence valproate concentrations? Drug Monit 2002;24:631-636.

9. Panayiotopoulos CP, Ferrie CD, Knott C, Robinson RO. Interaction of lamotrigine with sodium valproate. Lancet 1993;341:445.

10. Pisani F, Di Perri R, Perucca E, Richens A. Interaction of lamotrigine with sodium valproate. Lancet 1993;341:1224.

11. Guberman AH, Besag FM,Brodie MJ, et al. Lamotrigine-associated rash: risk/ benefit considerations in adults and children. Epilepsia 1999;40: 985-989.

12. Brodie MJ, Yuen AWC. Lamotrigine substitution study: evidence for synergism with sodium valproate? Epilepsy Res 1997;26:423-432.

13. Donaldson JA, Glauser TA, Olberding LS. Lamotrigine adjunctive therapy in childhood epileptic encephalopathy (the Lennox Gastaut syndrome). Epilepsia 1997;38:68-73.

14. Ferrie CD, Panayiotopoulos CP. Therapeutic interaction of lamotrigine with sodium valproate in intractable myoclonic epilepsy. Seizure 1994;3:157-159.

15. Veggiotti P, Cieuta C, Rey E, Dulac O. Lamotrigine in infantile spasms. Lancet 1994;344:1375-1376.

16. Trevathan E, Kerls SP, Hammer AE, Vuong A, Messenheimer JA. Lamotrigine adjunctive therapy among children and adolescents with primary generalized tonic-clonic seizures. Pediatrics 2006;118:e371-e378. 